\title{
The Phenomenon of Expletive Infixation in Vietnamese Language From the Perspective of Pragmatics
}

\author{
Nguyen Vi Thong \\ Dalat University, 01 Phu Dong Thien Vuong, Dalat, Vietnam \\ Nguyen Hoang Nhat Khanh \\ Dalat University, 01 Phu Dong Thien Vuong, Dalat, Vietnam \\ Nguyen Tat Thang \\ Dalat University, 01 Phu Dong Thien Vuong, Dalat, Vietnam \\ Nguyen Hoang Nhat Quyen \\ Dalat University, 01 Phu Dong Thien Vuong, Dalat, Vietnam \\ Tran Tin Nghi \\ Ho Chi Minh City University of Food Industry, Ho Chi Minh City, Vietnam

\begin{abstract}
Vietnamese has to date been considered to be a language without infixation. This study is an attempt to change that notion. Infixation does exist in the Vietnamese language, but in restricted discoursal and social contexts. Our analysis shows that infixes have pragmatic functions and convey one of three implications. They can be used to (1) to express a complaint, (2) to express disagreement, or (3) to enhance a compliment. For each pragmatic purpose, the social context must be considered so that offensiveness and impoliteness can be avoided. Our results reveal that the majority of the Vietnamese words containing the infix vói chả express complaints and that vói chả is most often inserted into nouns. This study provides Vietnamese language teachers, learners, and translators with an in-depth understanding of the Vietnamese infix vói chăa, as added into base words in certain styles of language play.
\end{abstract}

Index Terms - infixation, Vietnamese, expletive, social context, pragmatics, infix

\section{INTRODUCTION}

Infixation is not only a phenomenon of linguistics but also an expression of culture. Ultan (1975) claimed that infixes seem to be less familiar to students of linguistics than prefixes and suffixes even though all three belong to the phenomenon of affixation. According to $\mathrm{Yu}$ (2003, p. 2), infix can be defined as "an overt continuous morph that appears within a derived discontinuous morph that exists in a continuous form independent of the infixed form, and the individual parts of this resultant discontinuous morph must not be continuous morphs themselves." More succinctly, Mattiello (2013, pp. 186-187) defined infixation as a process in which an affix (infix) is inserted in the middle of a word. This description implies that infixes are distinct from other affixes in the way that they stand in the body of a base word. Mattiello (2013, p. 186) also reported that in some Indo-European and Austronesian languages, such as Greek and Atayal, infixes have important grammatical functions, whereas English has infixes "only within extra-grammatical morphology." In other words, infixes in English, for example, bloody in abso-bloodly-lutely and diddly in ac-diddlyaction, are employed mostly as expressive expletives for the purpose of additional emphasis.

Beljan (2015) stressed that infixation is a process that is not easy to describe due to its unpredictability and irregularity. As explained by Mattiello (2013), in most cases infixes function as intensifiers or emotive stress amplifiers. This implies that in English infixation serves a stylistic purpose. Thus, no difference is found between important and im-bloody-portant, or violin and vio-ma-lin. From these two examples, the only change that infixation conveys to the new word is related to its pragmatic meaning; in other words, this is a form of language play. It can also be seen from the examples that the infix does not change the grammatical category of the word or its meaning. Hence, after the infix -bloody - is inserted in the adjective important, im-bloody-portant still remains an adjective with the same semantic meaning.

\section{LITERATURE REVIEW}




\section{A. A Bird's-eye View of Infixation Across Languages}

As categorized by Beljan (2015), there are four relevant types of infixation in English: expletive infixation, diddlyinfixation, Homeric infixation, and hip-hop $i z$-infixation.

It is widely known that expletive infixation is used most frequently in the English-speaking community. Expletive infixation is defined by Beljan (2015) as the process of inserting an expletive or a profanity within a word with the purpose of emphasis and intensification. Moreover, Zwicky and Pullum (1987, p. 7) concluded that expletive infixation has "clear applicability to phrases alongside words" and "highly expressive colloquial effect." Beljan (2015) further observed that expletives are a phenomenon of both morphology and phonology. The following examples from McCarthy (1982) provide evidence for this case.

(1) English expletive infixation (McCarthy, 1982)

togethér

advánce

to-bloody-gether

Bhowáni

ad-bloody-vance

perháps

Bho-bloody-wani

enóugh

per-bloody-haps

impórtant

e-bloody-nough

Kalamazóo

im-fuckin-portant

Tatamagóuchee

Kalama-fuckin-zoo

Winnipesáukee

Tatama-fuckin-gouchee

Winnipe-fuckin-saukee

(Yu, 2003, p. 6)

Regarding these examples, Zwicky and Pullum (1987) listed the most frequently used expletives in English as bloody, blooming, frigging, $f^{* * * i n}(g)$, (god)damn, pissing, sodding, etc. As can be observed from examples (1) above, the position of the insertion of an infix into a word depends on the stress pattern of the word. It can clearly be seen that the expletive occurs prior to the stressed syllable. This observation argues against the claim that infixation in English is unpredictable and irregular (Mattiello, 2013).

Considered as a form of expletive infixation, diddly-infixation is actually a novel language game since "it shares with other language games the characteristic of being easily generalized by speakers to be applied to a variety of environments" (Elfner \& Kimper, 2008, p. 151).

(2) Canonical examples

\begin{tabular}{|c|c|}
\hline $\begin{array}{l}\text { wélcome } \\
\text { áction } \\
\text { múrder } \\
\text { órder } \\
\text { wélcome } \\
\text { órder }\end{array}$ & $\begin{array}{l}\text { wel-diddly-élcome } \\
\text { ac-diddly-áction } \\
\text { mur-diddly-úrder } \\
\text { or-diddly-órder } \\
\text { diddly-wélcome } \\
\text { diddly-órder }\end{array}$ \\
\hline
\end{tabular}

(Elfner \& Kimper, 2008, p. 151)

It is observed from example (2) that "the process involves infixation of the nonsense word diddly into a base word with initial stress as well as a reduplication of the rhyme and the stressed syllable" (Elfner \& Kimper, 2008, p. 151). Elfner and Kimper also explained that placing the infix - diddly - within the base with initial stress causes difficulties for stress assignment; therefore, the role of reduplication in these examples is to "allow the position of stress to remain faithful to its base form" (Elfner \& Kimper, 2008, p. 151).

Popularized by the television show, The Simpsons, the Homeric infixation or ma-infixation has recently become common in vernacular American English (Mattiello, 2013). The process is simply understood as the insertion of the infix $-m a$ - into words.

(3) The Simpsons example

Homer: Well, honey, what do you like? Tuba-ma-ba? Oba-ma-bo? That one? Saxa-ma-phone?

Homer: A hundred bucks? For a comic book? Who drew it, Micha-ma-langelo?

(Yu, 2003, p. 174)

$\mathrm{Yu}$ (2003) states that the main purpose of ma-infixation is humor. Yu also noted that the "meaning of this construction indicates roughly attitudes of sarcasm and distastefulness, although, it can also be used as a form of language play" (Yu, 2003, p. 174). Mattiello (2013) observed that Homeric infixation can be applied to words regardless of their grammatical categories, for example, noun (e.g., tele-ma-phone, vio-ma-lin), adjective (e.g., wonderma-ful), verb (e.g., underesti-ma-mate), participle (e.g., unsub-ma-stantiated), or even place/personal/river names (e.g., Ala-ma-bama, Micha-ma-langelo, Missi-ma-ssippi).

The final infixation that can be found in English is called $i z$-infixation. This phenomenon is derived from the American hip-hop community.

(4) Lyrics example

I'm still standin' strizong (strong)

And waitin' on my thrizone (throne)

And live for the dizzay (day) that God calls me hizome (home) 
Until then I'll rizzoam (roam), the face of the Izzerth (Earth)

And shoot for the stizars (stars), on days of my bizzerth (birth)

-Playa Fly, "N God We Trust"

(from Original Hip-Hop Lyrics Archive)

(Lindsay, 2010, p. 159)

Example (4) shows that the $i z$-infix is inserted before the stressed vowel. Therefore, if the word is monosyllabic, -izoccurs between the onset and the nucleus, for example, str-iz-ong. If the word is disyllabic, -iz- occurs before the stressed vowels, as in G-iz-óogle and beh-iz-áve (Mattiello, 2013). Mattiello also states that iz-infixation rarely occurs in words that have more than two syllables.

From these four types of infixation in English, it can be concluded that infixation is a process involving both morphology and phonology. Infixation does not have any grammatical function, so it does not affect the grammatical category of the infixed word. However, it is considered a case of language play when it indicates certain stylistic and pragmatic meanings.

In some languages, however, infixation can function as a grammatical process, which means that the infix can change the grammatical category of the word.

(5) Uradhi pluractional reduplication

$\begin{array}{lll}\text { wili } & \text { wilili } & \text { 'run' } \\ \text { arja } & \text { agaga } & \text { 'dig' } \\ \text { ipijii } & \text { ipipijii } & \text { 'swim' } \\ \text { wamp } & \text { wampampa } & \text { 'float' } \\ \text { ikya } & \text { ikikya } & \text { 'speak' }\end{array}$

(Crowley, 1983, p. 364)

Uradhi is a dialect of the Pama-Nyungan language in which the reduplicant copies the morphological and/or phonological unit of the base. In this language, pluractionality is marked by (C)CV reduplication, as shown in example (5). This implies that the infix changes the numeric feature of the base from singular to plural.

In other languages, infixation can result in changes in the part of speech of the infixed word.

(6) Mlabri nominalization (Rischel, 1995, p. 85).
a. guh 'to be ablaze'
kap 'to sing'
peelh 'to sweep the ground/floor'
tek 'to hit'
b. kwel 'to be rolled up'
gla? 'to speak'
pluut 'to peel'
klaap 'to hold'
gwerc 'to poke'
c. chreet 'to comb'

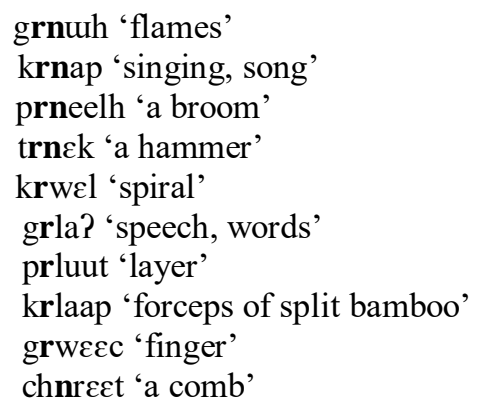

In all cases of example (6), the verbs become nouns after infixation, as also happens in the Mon-Khmer language. However, the process follows certain phonological rules. As in (6a), if the stem begins with a single consonant, the infix $-r n$ - occurs right after that consonant. If the stem begins with two consonants, the infix $-r-$ is used instead and inserted between the two consonants (6b). In the case of (6c), when the stem contains a rhotic in the initial consonants, the allomorph $-n-$ is employed and inserted before the rhotic.

It can be seen from the literature review that infixation exists in many dialects of languages. It plays different roles in each dialect. As native speakers of Vietnamese, the authors of this study attempt to examine the phenomenon of infixation in Vietnamese, which has been overlooked. Based on our observations, Vietnamese infixation is common in literary works and daily conversations. However, it has never been considered in an academic way; in other words, there has been no study on infixation in the Vietnamese language.

\section{B. Vietnamese Morphology and Term of Affixation}

As addressed many years ago by Thompson (1963), Vietnamese is a language that appears to be devoid of morphology; as a result, the argument about what constitutes a "word" has been continuously raised by linguists. Noyer (1998) classified Vietnamese as a canonically "isolating” language. It is obvious that Vietnamese lacks morphological markings for case, gender, number, and tense; thus, it has no finite/nonfinite distinction. A Vietnamese word may consist of a single morpheme or more than one morpheme. Polymorphemic words are either compound words or words consisting of stems plus affixes or reduplicants. As estimated in Nguyen (1976), roughly seven-tenths of Vietnamese dictionary entries are idiomatic polysyllabic collocations. Consider the following examples.

(7) Vietnamese morphology 


\begin{tabular}{|c|c|c|c|}
\hline Vietnamese word & English gloss & Phonological form & Morphological form \\
\hline (a) mura & "rain" & monosyllabic & monomorphemic \\
\hline (b) bếp núc & "kitchen chores" & disyllabic & monomorphemic \\
\hline (c) nhà tắm & "bathroom" & disyllabic & bimorphemic \\
\hline (d) vội vội vàng vàng & "hurry-scurry" & polysyllabic & polymorphemic (reduplicative) \\
\hline
\end{tabular}

In example (7a), the word mua has only one syllable and one morpheme. Example (7b) is a case of a word that has two syllables but only one morpheme, since, if we separate this word into two morphemes, núc conveys no meaning. On the other hand, (7c) shows a word that is both disyllabic and bimorphemic, since both morphemes have their own meaning. In this example, nhà means house and tắm means to take a shower. Thus, when they are combined, the meaning of the compound word can be understood as "a house (a room) where we can take a bath." Example 7(d) is an example of reduplication, which is very common in Vietnamese. The word contains more than two syllables and morphemes.

As analyzed in Noyer (1998), examples (7b) and (7c) can be categorized as two types of collocations: separable collocations and inseparable collocations, respectively. For example, bếp núc can be separated by the "idiom" vói, which means and, an overt conjunction. However, Noyer did not indicate the purpose of this linguistic phenomenon. In the case of (7c), it is claimed in Noyer (1998) that the word cannot be separated by any element. As native Vietnamese speakers, the authors of this study would argue against these two notions of Noyer. First, Noyer only used the term "idiom" in a general way to describe the function of vói, which in this paper is argued to be an infix. Second, the word nhà tắm in example (7c) can be separated by an infix, as will be demonstrated in Section 4.

It is widely known that the Vietnamese language has prefixes and suffixes. These two phenomena of affixation are taught and discussed in any Vietnamese language teaching program. The following examples provide some cases of affixation in Vietnamese.

(8) Vietnamese affixation

\begin{tabular}{|c|c|c|}
\hline Prefix/suffix & English gloss & Example \\
\hline (a) bán- & "half, semi-" & $\begin{array}{ll}\text { - } & \text { bán thân (body): a body half (upper/lower) } \\
\text { - } & \text { bán cầu (globe): semi-globe }\end{array}$ \\
\hline (b) phi- & "non-" & $\begin{array}{ll}\text { - } & \text { phi pháp (law): illegal } \\
\text { - } & \text { phi lợi nhuận (profit): non-profited }\end{array}$ \\
\hline (c) -hóa & "-ize, -fy" & $\begin{array}{l}\text { - } \quad \text { hiện đại (modern) hóa: modernization } \\
\text { - } \quad \text { a xít (acid) hóa: acidify }\end{array}$ \\
\hline (d) -gia & "profession, occupation" & $\begin{array}{l}\text { - phi hành (travelling to outer space) gia: astronaut } \\
\text { - } \quad \text { sử (history) gia: historian }\end{array}$ \\
\hline
\end{tabular}

It can be seen from these examples that prefixation and suffixation in Vietnamese are expressed very clearly. They each have their own function in grammar and semantics. Consider example (8a). The stem is thân, meaning body, which is a noun. After prefixation, the new word bán thân changes the meaning of its stem and grammatical category to become an adjective. The same pattern can be found in the remaining examples.

As mentioned above, the authors' observation is that Vietnamese language does have infixation, but somehow the phenomenon has been ignored and never closely examined by linguists. The present paper is an attempt to give the phenomenon academic consideration. The following sections provide an analysis of why the issue is worthy of study.

\section{MEthodOLOGY}

\section{A. Research Design}

This research mainly used a qualitative approach, but a quantitative method was also used. Examples of Vietnamese infixations were collected from social media and websites to form a dataset.

\section{B. Data Analysis}

After the data were collected, the samples were categorized into groups. The groups were then analyzed using descriptive statistics, and the size of each group was expressed as a percentage.

\section{FINDINGS AND DISCUSSION}

\section{A. Expletive Affixation in Vietnamese}

As stated previously, infixation in Vietnamese is commonly used in less formal contexts, such as movies, literature, and daily conversations. It is true that infixes do not have any grammatical or semantic function with regard to the stem; the infixation does not change the grammatical category or literal meaning of the infixed word. Therefore, like English, infixes in Vietnamese function as expletives and can be considered aspects of language play or style. The four most common infixes and infix clusters are examined in this study, as shown in Table 1. 
TABLE 1.

INFIXES AND INFIX CLUSTERS IN VIETNAMESE

\begin{tabular}{ll}
\hline Infix/Infix cluster & English gloss \\
\hline (1) - vói - & "-with/and-" \\
(2) - với chả- & "-with/and + neither/not-" \\
(3) - vói - cái gì & "-with/and-what" \\
(4) - với chả-cái gì & "-with/and + neither/not-what" \\
\hline
\end{tabular}

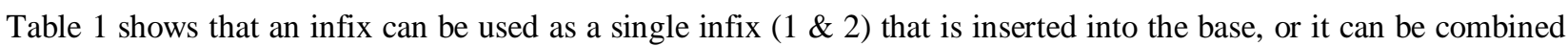
with other suffixes $(3 \& 4)$ to make up a cluster that is added to the stem. As the English gloss shows, the infixes have no clear "real" meanings. This means that these infixes are nonsense in terms of semantics, especially when they occur in collocations or clusters. The following examples show that infixes in Vietnamese are expletives. It should be noted here that all the examples of infixation in Vietnamese in this study were assessed by the first author, who is a native Vietnamese speaker. The data were then discussed with three other Vietnamese linguists to ensure acceptability. Therefore, the examples in this study are the best representatives of infixation in Vietnamese language usage.

Let us take a look at the following examples.

\begin{tabular}{|c|c|c|c|}
\hline Stem & English gloss & Stem description & Infixed word \\
\hline (5a) cà phê & coffee & Noun/disyllabic/ monomorphemic & $\begin{array}{l}\text { cà với phê } \\
\text { cà với chả phê } \\
\text { cà với phê cái gì } \\
\text { cà với chả phê cái gì }\end{array}$ \\
\hline (5b) vất vả & $\begin{array}{l}\text { tough/ difficult }+ \\
\text { reduplicant }\end{array}$ & Adj/disyllabic/ monomorphemic & $\begin{array}{l}\text { vất với vả } \\
\text { vất với chả vả } \\
\text { vất với vả cái gì } \\
\text { vất với chả vả cái gì }\end{array}$ \\
\hline (5c) học hành & $\begin{array}{l}\text { study }+ \text { practice } \\
\text { (meaning to study) }\end{array}$ & Verb/disyllabic/ bimorphemic & $\begin{array}{l}\text { học với hành } \\
\text { học với chả hành } \\
\text { học với hành cái gì } \\
\text { học với chả hành cái gì }\end{array}$ \\
\hline (5d) tắm táp & bathe + reduplicant & Verb/disyllabic/ monomorphemic & $\begin{array}{l}\text { tắm với táp } \\
\text { tắm với chả táp } \\
\text { tắm với táp cái gì } \\
\text { tắm với chả táp cái gì }\end{array}$ \\
\hline (5e) Sô cô la & chocolate & Noun/trisyllabic/ monomorphemic & $\begin{array}{l}\text { sô với cô la } \\
\text { *sô cô với la } \\
\text { sô với chả cô la } \\
\text { * sô cô với chả la } \\
\text { sô với cô la cái gì } \\
\text { * sô cô với la cái gì } \\
\text { sô với chả cô la cái gì } \\
\text { * sô cô với chả la cái gì }\end{array}$ \\
\hline
\end{tabular}

Example (5) clearly demonstrates the phenomenon of infixation in Vietnamese. It can be observed that the infixes can be added in words with upwards of two syllables, regardless of the number of morphemes or grammatical categories. Explicitly, whether the word is monomorphemic or bimorphemic does not affect the use of infixes. One more argument to show that infixes in Vietnamese are expletives is that they do not change the grammatical category of the words; rather, they retain the original meanings of the words. Also, it can be generalized that the infix is inserted after the first syllable of the base.

As mentioned above, this section argues against the analysis of Noyer (1998) that some of the listed words are inseparable. The word nhà tắm, shown in example (6) below, was considered inseparable by Noyer. The examples Noyer provided could be true if the expletive is not considered an infix. However, if the expletive is an infix, then the word nhà tắm can be separated. Example (6) shows that all four infixes can be inserted into the word nhà tắm, which was considered impossible by Noyer (1998).

(6) nhà tắm

nhà với tắm

nhà với chả tắm

nhà với tắm cái gì

nhà với chả tắm cái gì

In Vietnamese, the function of intonation is expressive. It adds to the cognitive meaning of the words in the utterance and indicates the attitude and emotion of the speaker. Moreover, the system of intonation, pause, and tone of voice can help to deepen understanding of speech. Diacritics are used to indicate the tones of Vietnamese. The tone markings are $a$ (no mark), à, á, ả, a, and $a$. They can be separated into two groups according to register: $a$, $a$, $\tilde{a}$ are realized in a higher register while $\grave{a}, a, a ̉$ are realized in a lower one. Therefore, of the four Vietnamese infixes that can be inserted into a word, the infix vói is realized in a higher register and infixes với chả, với-cái gì, and vói chả-cái gì are realized in a lower one. 
For example, a girl is walking on the street and a boy runs into her. She yells out in pain: "Tròi oí Đi vói đúng!'(Bold letters indicate primary stress.) This example shows that the Vietnamese infix vói expresses anger. Moreover, đi vói đúng makes up a sequence $a-a-a ́ a$ at a fairly high level because anger is expressed by a very high register and marked by a fast tempo.

From this evidence, it can be inferred that infixation in Vietnamese is very flexible and can be applied in many cases. As with English, infixation in Vietnamese has certain pragmatic implications that will be discussed in the next section along with the contexts for its use.

\section{B. Vietnamese Infixation from a Pragmatic Perspective}

The possibility of infixation allows us to note what the speaker's attitude is, which means that infixes in Vietnamese have a pragmatic meaning or play a pragmatic role.

The use of infixes depends greatly on the setting of the discourse. In particular, infixes are not used in contexts with a high level of formality. This means that social factors should be considered in the use of infixes. It is consciously understood by Vietnamese people that infixation can only be employed in certain situations and not in a spontaneous way. The issue implies that infixes do have certain pragmatic and social functions that show the user's language style.

In this study, the pragmatic functions of infixes are categorized into three groups by purpose: (1) to express a complaint, (2) to express disagreement, and (3) to enhance a compliment.

\section{Complaint}

Infixes are mainly used in Vietnamese to express negative attitudes. Infixation is a type of language play in which users emphasize their ideas or opinions. The most common use of infixes is to express a complaint. Consider the following example and its context.

(7) A mother is talking to her son.
Mother:
Con với chả cái!
Học với hành chả ra gì!
child INFIX REDUPLICANT Study INFIX practice not show what
What a bad child!

(8) Two friends are talking to each other.

Person 1: Thời với chả tiết cái gì mà như chảo lửa!
weather INFIXXXX SUFFIX like pan fire

The weather is as hot as fire.

Example (7) shows the pragmatic function of infixes in Vietnamese. By inserting the infix into a base, we can clearly grasp the implication that the mother is complaining about her son's performance. This can be seen as an interesting linguistic phenomenon that can rarely be found in other languages. It should be noted that the context for using infixes in complaints is very limited. There should be a certain power relationship between the people involved. Infixes can only be used by people with a higher social status or familial relationship, or among people with the same social status. Those who are younger or of lower social status should be very careful not to use infixes with elderly people or people with higher status; otherwise, it could be considered offensive.

In example (8), the conversation takes place between two friends. This is slightly different from the previous example in that the speaker is trying to judge a subjective entity. It has no purpose to blame or offend on any subjective matter. In this case, without the infixation, the sentence already has its own implication of complaining about the weather. The inserted infix cluster emphasizes the level of seriousness of the matter. In other words, the infixation makes the complaint stronger. In this case, the sentence could be uttered by a son to his mother without offense.

Therefore, the implication of infixation can vary in different social contexts. Even though infixes show complaints, their use still depends upon the target of the complaint. This phenomenon requires Vietnamese learners to have a solid knowledge and understanding of the language.

\section{Disagreement}

Another interesting use of infixation in Vietnamese is to express disagreement without adding any structures of negation. Consider the following examples.

(9) A son is talking to his mother.

Son: Me cho con xin it tiền nhé!
Mom let me insist some money EXCLAIMER
Couldyou give me some money, Mom?
Mother: Tiền với bạc cái gì. $\quad$ Con xài nhiều quá rồi đó.
Money INF coin SUF you spendmuch so already
No way! You have spent so much already.

(10) Two friends are talking to each other.

$\begin{array}{rlr}\text { Person 1: Đi uống cà phê } & \text { không? } \\ \text { go drink } & \text { coffee } & \text { QUESTION WORD } \\ \text { Wanna go to the café? } & \\ \text { Person 2: Cà với chả phê. } & \text { Đang bận rồi. }\end{array}$




\section{Coffee INF XXX Being busyalready}

No way! Busy now!

Examples (9) and (10) illustrate how infixation is used with an implication of disagreement. It is of interest that with only the infix inserted into the base, the implication of disagreement is expressed very clearly. It can be seen from the gloss that no words of negation occur in either example. However, the social factor should be carefully considered here as well. It would be very inappropriate if these two sentences were uttered by a son to his mother. This could imply that disagreement with infixation is very strong, and there seems to be no possibility that the speaker will change his or her mind. In short, infixation can be used to disagree with a suggestion or request, but it should be used in the right context; otherwise, the listener may feel offended.

\section{Enhancement of a Compliment}

Fortunately, infixation in Vietnamese conveys not only negative implications, but can convey a positive implication as well. Let us consider the following example.

(11) This is a comment on a video of a woman cooking.

Đám vói đang thé này mà ngừ̀i ta không thích mói là lạ.
Capable INF RED like this but people not like then to be weird
(reduplicative)

It would be weird if someone doesn't like a capable person like her.

(11') This could not be expressed with other infixes:

* Đám với đang thé này mà người ta không thích mór là lạ.

* Đảm với chả đang thế này mà người ta không thích mói là lạ.

* Đảm với chả đang cái gì thế này mà người ta không thích mới là lạ.

* Đảm với đang cái gì thế này mà người ta không thích mói là la.

Example (11) illustrates how infixation is used to enhance a certain positive attitude toward a target object. It can be seen that, without the infixation, the sentence itself already has the implication of a compliment; however, the occurrence of the infix helps enhance the compliment. This means that the infix helps emphasize the positive meaning of the stem. In this case, the infix can be used to express a positive attitude toward those who are of higher social status, but only in informal settings. However, -vói- is the only infix that can be used to imply enhancement. The other infixes shown in (11') are inappropriate for this purpose, which indicates that infixation is not flexible for this usage.

\section{Quantitative Analysis}

Despite being rarely used in formal writing, Vietnamese infixes can be heard in colloquial language, daily conversations, short stories, online news, and social networks nowadays. The dataset in this study was obtained from various online sources, including Facebook, TikTok, Twitter, YouTube, Instagram, Flickr, Forum, online news, online stories, and other websites.

The researchers collected 165 samples of infixations. The data consist of 4 samples of với, 146 samples of với chả, 13 samples of với-cái gì, and 2 samples of với chả-cái gì. The research focused on analyzing the với chả sample data because mostly với chả samples were collected. Descriptive statistics were calculated and the results were expressed as percentages.

The researchers have collected the data of the actual process with 4 samples of với, 146 samples of với chả, 13 samples of với-cái gì and 2 samples of với chả-cái gì. Despite being rarely used in formal writing, Vietnamese infix can be heard and used in colloquial language, daily conversations, short stories, news online, and social networks nowadays. In this study, the researchers focused on analyzing the data of với chả samples which were handled using descriptive statistics expressed as a percentage because với chả samples were collected the most.

The data set used in this study were obtained from different online sources. The data specific to this research were collected from Facebook, Tiktok, Twitter, Youtube, Instagram, Flickr, Forum, news online, story online and other websites. The number of samples found was 165, within which 146 were identified as eligible for sample of với chả. Therefore, the results of this research were only based on 146 samples of với chả.

Hereafter Table 2 lists some Vietnamese words containing the infix với chả collected for this study. 
TABLE 2.

A List OF SOME VIETNAMESE WORDS CONTAINING THE INFIX Vórl CHả

\begin{tabular}{|c|c|c|c|c|}
\hline Ăn vói chả nói & Chồng với chả con & Giận với chả hờn & Lên với chả xuống & $\begin{array}{l}\text { Thầy bói với chả thầy } \\
\text { bủng }\end{array}$ \\
\hline Ăn với chả uống & Con với chả cái & Giàu với chả nghèo & Mưa với chả gió & Thi vớ chả cử \\
\hline Anh với chả em & Con với chả cháu & Giày với chả dép & Nói với chả năng & Tiền với chả bạc \\
\hline Áo với chả quần & Cúng với chả kiếng & Hẹn với chả hò & Ôm ấp với chả vuốt ve & Tóc với chả tai \\
\hline Bạn với chả bè & Đáng với chả yêu & Hình với chả bóng & Ôm với chả ấp & Trà với chả sữa \\
\hline Béo với chả béo & Đậu xanh với chả đậu đỏ & Hóng với chả hớt & Ong với chả bướm & Tuyệt với chả vời \\
\hline Bói với chả toán & Đi với chả đứng & Hứa với chả hẹn & Phim với chả ảnh & Xe với chả cộ \\
\hline Cao với chả lùn & Đồng với chả phục & Hứa với chả hèo & Quần với chả áo & Xin vói chả xỏ \\
\hline Chân với chả tay & Du với chả lịch & Khóc với chả lóc & Sách với chả vở & Xinh với chả đẹp \\
\hline Chị với chả em & Giận với chả dỗi & La với chả hét & Thần với chả thoại & Yêu với chả đương \\
\hline Chó với chả mèo & & & & \\
\hline
\end{tabular}

(See the Appendix for the sources.)

When the Vietnamese infix vói chả is inserted into a word stem, the original meaning of the word generally does not change. However, vói chả influences the listener's emotions and expresses the speaker's attitude in a particular rhetorical situation. As discussed above, vói chả can convey one of three implications in the infixed words: (1) to express complaint, (2) to express disagreement, or (3) to enhance a compliment. Figure 1 illustrates the frequency with which vói chả is used to convey each implication in infixed words. Of 146 Vietnamese words containing the infix với chả, $80.14 \%$ express a complaint, $10.96 \%$ express disagreement, and $8.90 \%$ enhance a compliment.

\begin{tabular}{|ll|}
\hline $10.96 \%$ & Express complaint \\
& Express disagreement \\
$80.14 \%$ & $\begin{array}{l}\text { Enhance the degree of } \\
\text { compliment }\end{array}$ \\
\hline
\end{tabular}

Figure 1. Use of the Infix với chả by Implication

As can be seen from the pie chart in Figure 1, the majority of the Vietnamese words containing the infix với chả are used to express complaints. Many people often post their status on Facebook to express a negative attitude toward some topic. For example, thi với chả cử shows the bad feeling of not getting good exam results. After complaining, their mental state may improve when their friends comment to encourage them. In contrast, only $10.96 \%$ of Vietnamese words containing the infix vói chả expressed disagreement. Most of them include an expression of refusal and a reason. For example, the sentence, “夰 với chả uống gì tầm này nữa, trễ rồi," expresses disagreement very clearly, and the reason for it is late time. However, people can suffer from a sense of disagreement. Why are they so bothered by good friends refusing their requests or declining their invitations posted on Facebook? Why does it ruin their mood? Why would something so seemingly insignificant make them feel angry with their friends and relatives? The reason is that many people fear disagreement. If they have experienced it once or a few times, they probably remember how much it hurt and worry about it happening again. Finally, a minority of usages (8.90\%) enhanced a compliment. The example, "Xinh với chả đẹp nhu gia đình chị thì ai chẳng thích chị oi,", illustrates how the Vietnamese infix với chá is used to enhance a positive attitude toward gia dinh chị. Thus, the infix với chả helps enhance a compliment. This example is from a comment on Facebook by a fan of a famous singer. This means that the infix vói chả can be used to express positive attitudes toward those who are of higher social status, but, of course, only in informal settings.

Importantly, as illustrated in Figure 2, a significant majority of the Vietnamese words containing the infix vói chả $(47.06 \%)$ are inserted into nouns that refer to objects, people, and more sophisticated abstract concepts. Some Vietnamese nouns containing the infix vói chả can change their implications depending on how they are used and what combinations they form. For example, the sentence, “...chồng với chả con, cút đẹp trai thế này ai mà chịu đượ...," illustrates how the Vietnamese infix với chả is used to enhance a compliment. On the other hand, với chả expresses a complaint in "Chồng Với Chả Con, Chán Xỉu." Therefore, expressing a negative or positive attitude toward some matter depends on the context.

A large proportion of Vietnamese words containing the infix vói chả $(41.18 \%)$ are verbs used in everyday conversations and emotional expressions. These uses can be easily categorized as complaints, expressions of disagreements, or enhancements of compliments. The phrase ôm vói chả ấp provides an illustration. First, the writer of an online short story used the phrase, ...ôm với chả ấp, còn không mau đõ anh mày ngồi dậy..., to express a complaint. Second, a sentence, Lón rồi còn đòi ôm với chả ấp, em nó cười cho, collected from a website exemplifies a disagreement. Finally, the phrase ôm vớ chả ấp is used to enhance a compliment. The writer posted this phrase with a picture on Instagram of herself hugging her boyfriend to show their happiness. 
Finally, a minority of the Vietnamese words containing the infix vói chả (11.76\%) are adjectives. People always use adjectives to make their expressions more visual and vivid, so the implications that Vietnamese infix với chả can convey with the infixed words are clearer. Readers or listeners will get a better idea of what speakers or writers wish to bring to their attention or to picture in their minds when they read or listen to messages containing infixations.

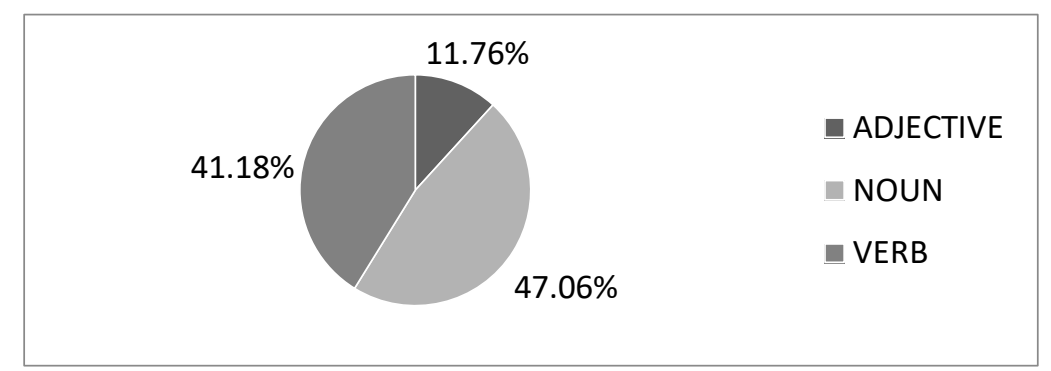

Figure 2. Percentage Use of với chả in Three Parts of Speech

\section{CONCLUSION}

This paper investigates the phenomenon of infixation in Vietnamese, which has been overlooked by linguists. The analysis shows that Vietnamese infixes are expletives added to base words in certain styles of language play. However, in terms of pragmatics, the functions of infixation in Vietnamese are more obvious. Infixes can be used to express complaints and disagreements, and to enhance compliments. It should be noted that the context in which the discourse takes place must be carefully considered; otherwise, listeners may take offense or feel the expression is impolite. This study has not considered the grammatical roles of infixed words in sentences, which we suggest as a topic of future research. Despite this limitation, this study challenges the traditional notion of affixation in Vietnamese, which we consider its main contribution.

\section{ACKNOWLEDGEMENTS}

We were fortunate to be financially supported by Dalat University and would like to express our deepest gratitude and appreciation to Dalat University for encouraging us to pursue our research path.

\section{APPENDIX}

\begin{tabular}{|c|c|c|}
\hline 1 & $\underline{\text { https://khosachonline.com/sach/cinderella-12-gio }}$ & $\begin{array}{l}\text { Gì mà mắng mỏ dạy dỗ, cắt khẩu } \\
\text { phần bánh quy, xong lại ôm ấp với } \\
\text { chả vuốt ve }\end{array}$ \\
\hline 2 & https://www.facebook.com/tamsuhv/posts/333228803521292/ & $\begin{array}{c}\text { Ăn với chả nói đọc tóm gọn lại vẫn là } \\
\text { hỗn xược }\end{array}$ \\
\hline 3 & https://tinhte.vn/thread/an-voi-cha-noi.3189030/ & Ăn với chả nói... \\
\hline 4 & https://www.facebook.com/110906550361892/posts/593572772095265/ & $\begin{array}{l}\text { Bảo Lộc tới công chuyện, đã dịch } \\
\text { còn bói với chă toán. }\end{array}$ \\
\hline 5 & $\begin{array}{c}\text { http://hoicodo.com/511179/chet-do-an-voi-cha-noi-noi-vay-nhung-nguoi-viet-quoc-gia- } \\
\text { ti-nan-cong-san-lai-khoc-len-gio/ }\end{array}$ & Chết dở. Ăn với chả nói. \\
\hline 6 & https://www.cuoida.com/p/an-voi-cha-uong-1 & Ăn với chả uống \\
\hline 7 & $\begin{array}{c}\text { https://lazi.vn/photo/album/d/37017/an-voi-cha-uong-co-beo-len-can-nao-dau-co-chu- } \\
\text { chi-map-len-thui }\end{array}$ & $\begin{array}{l}\text { Ăn với chả uống, có béo lên cân nào } \\
\text { đâu cơ chứ, chỉ mập lên thui }\end{array}$ \\
\hline 8 & https://www.flickr.com/photos/77782854@N07/7844730920/ & $\begin{array}{c}\text { Bởi ăn với chả uống =)))) phải ghi } \\
\text { nhớ từng giai đoạn khi ăn LOL } \\
\text { "Nhìn" - "Bỏ miệng" - "Cắn" - } \\
\text { "Nhai" }\end{array}$ \\
\hline 9 & $\begin{array}{c}\text { https://www.cuoida.com/p/nghi-lo-chan-anh-voi-cha-em-nhin-mat-nhau-khong-chui- } \\
\text { nhau-la-con-may }\end{array}$ & $\begin{array}{l}\text { Anh với chả em, nhìn mặt nhau, } \\
\text { không chửi nhau là còn may }\end{array}$ \\
\hline 10 & $\begin{array}{c}\text { https://forum.568play.vn/index.php?threads/haitacvl-\%C3\%81o-v\%E1\%BB\%9Bi- } \\
\text { ch\%E1\%BA\%A3-qu\%E1\%BA\%A7n.51356/ }\end{array}$ & Áo với chả quần \\
\hline 11 & https://comi.mobi/truyen/den-comics/ban-voi-cha-be/ & Bạn với chả bè \\
\hline 12 & https://xem.vn/ban-voi-cha-be-1362679.html & Bạn với chả bè \\
\hline 13 & https://www.webtretho.com/f/tam-su-chuyen-doi/ban-voi-cha-be-lai-ban-than-227161 & Bạn với chả Bè - lại bán than \\
\hline 14 & https://www.comico.vn/comicolours/title/555 & Bạn với chả bè \\
\hline 15 & $\begin{array}{c}\text { https://kilopad.com/truyen-cuoi-c198/doc-sach-truc-tuyen-truyen-cuoi-dan-gian-viet- } \\
\text { nam-b4918/chuong-9-phan-9-ti9 }\end{array}$ & $\begin{array}{l}\text { Cá đây, chứ đâu phải thịt mỡ đâu mà } \\
\text { béo với chả béo! }\end{array}$ \\
\hline 16 & https://www.facebook.com/neuconfessions/posts/1493325967383957/ & $\begin{array}{l}\text { Đấy bói với chả toán, hay phải có } \\
\text { thờ mới có thiêng, vì mình ko thờ } \\
\text { nên THẦY bói sai cho }\end{array}$ \\
\hline 17 & https://www.otofun.net/threads/cac-cu-co-tin-vao-phong-thuy-k-a.1433773/ & $\begin{array}{l}\text { Bói với chả toán số người ta sướng } \\
\text { không phải làm vẫn có ăn có mặc } \\
\text { dám kêu khổ chết là đáng! }\end{array}$ \\
\hline
\end{tabular}




\begin{tabular}{|c|c|c|}
\hline 18 & $\frac{\underline{\text { https://www.nguoiduatin.vn/bat-ngo-voi-thu-nhap-khung-cua-thay-boi-via-he- }}}{\underline{\text { a38123.html }}}$ & $\begin{array}{l}\text { Mất tiền thêm lo, may mà có } 20.000 \\
\text { đồng, bói với chả toán, thế mà nhiều } \\
\text { người vẫn lao vào", Việt than thở. }\end{array}$ \\
\hline 19 & $\frac{\text { https://www.yan.vn/chang-trai-kho-tram-duong-vi-trot-thich-co-gai-me-boi-toan- }}{\underline{157753 . h t m l}}$ & $\begin{array}{l}\text { "Mất người yêu vì bói với chả } \\
\text { toán !!! Có ai hiểu cảm giác của mình } \\
\text { không ? }\end{array}$ \\
\hline 20 & $\underline{\text { https://anninhthudo.vn/boi-voi-toan-post67885.antd }}$ & $\begin{array}{l}\text { nỗ lực, đoàn kết, tích cực làm ăn thì } \\
\text { phất chứ bói với chả toán. }\end{array}$ \\
\hline 21 & https://ask.bigbrothers.top/question/bai-tarot-boi-the-nao-duoc-nhi/ & $\begin{array}{l}\text { Vậy cái bài torot mà người ta có thể } \\
\text { vẽ được thì có cái mẹ gì đâu mà đòi } \\
\text { bói với chả toán, mấy ông cứ khè } \\
\text { thiên hạ đúng lắm đúng lắm. }\end{array}$ \\
\hline 22 & $\begin{array}{l}\frac{\text { https://books.google.com.vn/books?id=ZPrxCwAAQBAJ\&pg=PT49\&lpg=PT49\&dq=1 }}{\text { \%C3\%AAn+v\%E1\%BB\%9Bi+ch\%E1\%BA\%A3+xu\%E1\%BB\%91ng\&source=bl\&ots }} \\
\text { =bfhV24hODa\&sig=ACfU3U0NPFvzud- } \\
\frac{\text { w8eFheizk61pB_i4Bhg\&hl=vi\&sa=X\&ved=2ahUKEwiVgbLficfzAhWH62EKHc5SD }}{\text { OgQ6AF6BAgkEAM\#=onepage\&q=1\%C3\%AAn\%20v\%E1\%BB\%9Bi\%20ch\%E1\% }} \\
\text { BA\%A3\%20xu\%E1\%BB\%91ng\&f=false }\end{array}$ & Chân với chả tay thế đấy \\
\hline 23 & https://www.youtube.com/watch?v=4QGUMaZUe7s & $\begin{array}{l}\text { Chân với chả tay, hok chịu nghe lời } \\
\text { bấm móng gì cả }\end{array}$ \\
\hline 24 & https://www.facebook.com/Sammishop.com86/posts/3579728625401151/ & Ơ, chị với chả em, nghèo bay mà \\
\hline 25 & "https://xabuon.com/content/274216-chi-voi-cha-em---3.htm & Chị với chả em \\
\hline 26 & "https://www.facebook.com/watch/?v=850983458598833 & Chó \\
\hline 27 & https://dantri.com.vn/tinh-yeu-gioi-tinh/chong-voi-cha-con-1355271194.htm & Chồng với chả con \\
\hline 28 & https://www.facebook.com/watch/?v=541542776458662 & Chồng với chả con \\
\hline 29 & https://www.youtube.com/watch?v=eFdLJgOrRFo & Chồng Với Chả Con, Chán Xỉu \\
\hline 30 & https://www.youtube.com/watch?v=5kep7vWfyd0 & Chồng với chả con \\
\hline 31 & https://www.youtube.com/watch?v=1ZCNQsRrFe8 & Ơi Là Trời Chồng Với Chả Con \\
\hline 32 & https://www.youtube.com/watch?v=_jHSJ-pFmPc & Chồng với chả con \\
\hline 33 & https://www.youtube.com/watch?v=XzmO2ebM2oQ & Chồng với chả con, chán \\
\hline 34 & https://www.youtube.com/watch?v=Cum Mw7dC3o & Chồng với chả con \\
\hline 35 & $\begin{array}{c}\text { https://www.cuoida.com/p/chong-voi-cha-con-chan-cha-buon-noi-hwanglong-welax- } \\
\text { xem-them-nhieu-hinh-anh-cuoi-tet-ga-xa-stress-ta }\end{array}$ & $\begin{array}{c}\text { Chồng với chả con. Chán chả buồn } \\
\text { nói }\end{array}$ \\
\hline 36 & https://mobile.twitter.com/toantran20cm/status/1410114137762320387 & Chồng với chả con \\
\hline 37 & http://www.mamnon.com/newsDetails.aspx?topicID $=51530$ & $\begin{array}{l}\text { rồi anh Tiến quay sang người khách } \\
\text { nói: Con với chả cái, bướng lắm bác } \\
\text { ạ. }\end{array}$ \\
\hline 38 & $\frac{\frac{\mathrm{https}: / / \text { www.facebook.com/SpeakYourDream/photos/con-v\%E1\%BB\%9Bi- }}{\mathrm{ch} \% \text { E1\%BA\%A3-c\%C3\%A1i-con-v\%E1\%BB\%9Bi-ch\%E1\%BA\%A3-c\%C3\%A1i- }}}{\frac{\text { su\%E1\%BB\%91t-ng\%C3\%A0y-ch\%C6\%A1i-\%C4\%91i\%E1\%BB\%87n- }}{\text { t\%E1\%BB\%ADcon-v\%E1\%BB\%9Bi-ch\%E1\%BA\%A3-c\%C3\%A1i- }}}$ & $\begin{array}{c}\text { "Con với chả cái suốt ngày chơi điện } \\
\text { tử" } \\
\text { "Con với chả cái suốt ngày đàn đúm } \\
\text { bạn bè” } \\
\text { "Con với chả cái suốt ngày nhốt } \\
\text { mình trong phòng chả phụ bố mẹ } \\
\text { được việc gì" }\end{array}$ \\
\hline 39 & $\frac{\text { https://thanhnien.vn/thoi-su/lay-72-ti-dong-tu-ngan-sach-den-ong-chan-con-voi-cha- }}{\underline{\text { cai-571853.html }}}$ & $\begin{array}{l}\text { "Con với chả cái!", những người lớn } \\
\text { tuổi, các bậc sinh thành đôi khi hay } \\
\text { dùng câu này nói về lớp con cháu } \\
\text { mình, khi chúng không làm cho họ } \\
\text { hài lòng. }\end{array}$ \\
\hline 40 & https://giadinh.ne & con với chả cái, bướng lắm bác ạ. \\
\hline 41 & $\begin{array}{c}\text { https://www.trungtamphuchoichucnang.com/am-ngu-tri-lieu/32-cau-noi-cua-mieng- } \\
\text { cua-phu-huynh-khien-tre-ton-thuong-tam-ly-nang-ne.html }\end{array}$ & $\begin{array}{l}\text { Con với chả cái, càng lớn càng hư, } \\
\text { không coi bố mẹ ra gì. }\end{array}$ \\
\hline 42 & https://nhandan.vn/truyen-ngan_1/toc-dai-276392 & $\begin{array}{c}\text { Tất nhiên là mè trách, con với chả } \\
\text { cái, tiếc chi mà không báo trước cho } \\
\text { mẹ }\end{array}$ \\
\hline 43 & https://www.facebook.com/watch/?v=1966219313518415 & $\begin{array}{l}\text { Con với chả cháu tặng bà con này ai } \\
\text { mà dám nhận. }\end{array}$ \\
\hline 44 & https://cand.com.vn/Phong-su-tu-lieu/Ruoc-hoa-dau-nam-vi-tin-thay-boi-i510343/ & $\begin{array}{l}\text { Cúng với chả kiếng, tôi đã bảo đưa } \\
\text { con đi viện mà không nghe }\end{array}$ \\
\hline 45 & $\begin{array}{c}\frac{\text { https://m.facebook.com/groups/2173232296086082/posts/T\%C3\%A1o- }}{\text { khuy\%E1\%BA\%BFt-posted-in-H\%E1\%BB\%99i-C\%C3\%A1c-M\%E1\%BA\%B9- }} \\
\frac{\text { B\%E1\%BB\%89m-S\%E1\%BB\%AFa-H\%E1\%BA\%A3i-Ph\%C3\%B2ng- }}{\text { '/4144779442264681/ }}\end{array}$ & Đậu xanh với chả đậu đỏ! \\
\hline 46 & https://www.facebook.com/watch/?v=795482504171741 & Đi với chả đứng kiểu này đây \\
\hline 47 & https://www.cuoida.com/p/di-voi-cha-dung & Đi với chả đứng \\
\hline 48 & https://www.facebook.com/saintsup.vnfc/posts/709223209445527/ & Đi với chả đứng kiểu gì chả hiểu? \\
\hline 49 & $\begin{array}{l}\text { https://www.webtretho.com/f/tam-su-chuyen-doi/chuyen-vo-van-thuong-ngay-o-huyen- } \\
\underline{\underline{324055}}\end{array}$ & Tiên sư mày, đi với chả đứng. \\
\hline 50 & https://www.facebook.com/PerthsaintVN/posts/430880887670785/ & Đi với chả đứng \\
\hline 51 & https://dep.com.vn/dong-voi-cha-phuc/ & Đồng với chả phục, sốt ruột! \\
\hline 52 & https://truyen4u.net/bangpink-vi-ngot-tinh-yeu-63-nhat-ki-gian-hon-719798242.html & $\begin{array}{l}\text { cô Manoban xuống dưới nhà gặp tôi } \\
\text { mau, giận với chả dỗi }\end{array}$ \\
\hline 53 & ss://www.fic & Giân với chả hờn \\
\hline 54 & https://truyenfic.com/doc-chuong/series-nct-couple-markhyuck-nomin-3- & Ơ đây còn giận với chả hờn. \\
\hline
\end{tabular}




\begin{tabular}{|c|c|c|}
\hline & & \\
\hline 55 & https://www.instagram.com/cuongtonyy & $\begin{array}{l}\text { Có sống ở đời mãi đâu mà giận với } \\
\text { chả hờn }\end{array}$ \\
\hline 56 & $\frac{\text { https://truyenkul.net/chapter/vkook-text-classmates-kth-jik-25- }}{\text { messenger/626492676.html }}$ & $\begin{array}{l}\begin{array}{l}\text { Ngủ rồi hả? Bớt ồn ào ... Giận với } \\
\text { chả hờn }\end{array} \\
\end{array}$ \\
\hline 57 & $\begin{array}{l}\text { http://forum.ngocrongonline.com/app/index.php?for=forum\&do=list\&uid=18764525\& } \\
\qquad \mathrm{p}=0 \& \mathrm{sz}=15\end{array}$ & $\begin{array}{l}\text { Giàu với chả nghèo, sự thật là t chưa } \\
\text { nạp } 1 \text { xu nào vào game mà đồ săn } \\
\text { boss đồ các kiểu }\end{array}$ \\
\hline 58 & https://www.facebook.com/blogtamsu.fanpage/posts/2002752273315588/ & $\begin{array}{l}\text { Giày với chả dép, chỉ muốn cởi nó ra } \\
\text { rồi đốt nó ngay và luôn. }\end{array}$ \\
\hline 59 & https://www.youtube.com/watch?v=sPJI3GrWv9I & Hóng với chả hớt \\
\hline 60 & https://www.youtube.com/watch?v=AQ1P-BKefB4 & $\begin{array}{l}\text { Em bé lắm chuyện. Ăn không lo ăn } \\
\text { mà hóng với chả hớt. Ớn à. }\end{array}$ \\
\hline 61 & https://www.facebook.com/2363196613944916/posts/2549095118688397/ & Hóng với chả hớt \\
\hline 62 & " https://www.youtube.com/watch?v=HidT9P3dujE & Hứa với chả hẹn :< \\
\hline 63 & https://www.facebook.com/100016704968748/videos/630355464197947/ & Hứa với chả hẹn \\
\hline 64 & $\begin{array}{l}\text { https://www.cuoida.com/p/hua-voi-cha-hen-the-nen-chi-em-cu-phai-di-choi-nhieu-vo- } \\
\text { sau-do-moi-lay-chong-nhe } \\
\end{array}$ & $\begin{array}{c}\text { Hứa với chả hẹn, thế nên chị em cứ } \\
\text { phải đi chơi nhiều vô, sau đó mới lây } \\
\text { chồng nhe }\end{array}$ \\
\hline 65 & https://www.cuoida.com/2020/04/hua-voi-cha-hen_16.html & Hứa với chả hẹn \\
\hline 66 & https://www.facebook.com/yenhtplus/videos/293068485307264/ & Hứa với chả hẹn \\
\hline 67 & https://www.youtube.com/watch?v=OAsHFFbOQL4 & Khóc với chả lóc:))) \\
\hline 68 & https://www.facebook.com/vtcnewsvn/posts/1451789881607967/ & $\begin{array}{l}\text { Khóc với chả lóc, thanh niên sức dài } \\
\text { vai rộng... }\end{array}$ \\
\hline 69 & https://www.facebook.com/watch/?v=1492027724317244 & $\begin{array}{l}\text { Buồn thì nhậu làm đell gì mà phải } \\
\text { khóc với chả lóc }\end{array}$ \\
\hline 70 & $\frac{\underline{\text { https: } / / \text { www.facebook.com/permalink.php?id=111061336905861\&story_fbid=4455312 }}}{\underline{76792197}}$ & $\begin{array}{l}\text { Đừng tự nghĩ rồi tự khóc với chả lóc } \\
\text { ai dẹp poster thì cho em chứ em còn } \\
\text { không có mà dẹp }\end{array}$ \\
\hline 71 & https://www.xaluanvnn.com/modules.php?name=News\&file=article\&sid=2738509 & $\begin{array}{l}\text { Mè đẻ khóc tiễn tôi lên xe hoa, mẹ } \\
\text { chồng lườm: 'Khóc với chả lóc, làm } \\
\text { như đi chết không bằng' }\end{array}$ \\
\hline 72 & https://tamsucongso.com/lop-1/ & $\begin{array}{l}\text { Hứa với chả hẹn...Khóc với chả } \\
\text { lóc... }\end{array}$ \\
\hline 73 & $\begin{array}{c}\text { https://iuhers.com/cdm/ngay-be-giang-khoc-loc-hua-hen-khi-20-11-ru-7-dua-khoc-to- } \\
\text { nhat-dam-thi-diu-dua-nao-ve.html }\end{array}$ & $\begin{array}{c}\text { Hứa với chả hẹn... Khóc với chả } \\
\text { lóc... }\end{array}$ \\
\hline 74 & $\begin{array}{c}\text { https://datviet.trithuccuocsong.vn/van-hoa/tin-tuc-giai-tri/lo-tin-nhan-thu-minh-goi-la- } \\
\text { nathan-lee-lacon-cho-2364148/ }\end{array}$ & $\begin{array}{l}\text { Điên à, vậy thì hát bài khác, khóc với } \\
\text { chả lóc! }\end{array}$ \\
\hline 75 & $\begin{array}{c}\text { https://guu.vn/diem-tin/hom-nay-chia-tay-buon-thi-cu-khoc-di-chuyen-hop-lop-de- } \\
\text { ngay-sau-roi-tinh-5d099ca45242f41b79199ebf.html }\end{array}$ & $\begin{array}{l}\text { 'Lúc ra trường thì khóc với chả lóc } \\
\text { rồi chống mắt lên xem đến lúc gọi } \\
\text { họp lớp được bao nhiêu đứa thèm đi.' }\end{array}$ \\
\hline 76 & https://o.voz.vn/showthread.php?p=59084539 & Khóc với chả lóc, nhớ với nhung \\
\hline 77 & 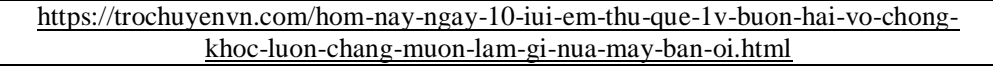 & Có gì mà khóc với chả lóc chứ. \\
\hline 78 & m/truyen/dinh-cap-thieu-nien/chuong-102-2/ & $\begin{array}{l}\text { Lại thêm một người, hôm nay là đám } \\
\text { ma ai vậy, khóc với chả lóc. }\end{array}$ \\
\hline 79 & $\begin{array}{c}\text { https://soha.vn/nhay-vao-be-ca-rong-choi-nguoi-chong-mat-50-trieu-ngay-tuc-khac-va- } \\
\text { cai-ket-khoc-het-nuoc-mat-20191001145314519.htm }\end{array}$ & $\begin{array}{l}\text { Giờ thì ngồi đấy mà khóc với chả } \\
\text { lóc. }\end{array}$ \\
\hline 80 & $\begin{array}{l}\text { https://thethaovanhoa.vn/video/giai-tri/xem-nguoc-chieu-nuoc-mat-tap-16-khan-gia- } \\
\text { phat-ngan-vi-mai-chi-biet-khoc-loc-n20171110144730076.htm }\end{array}$ & $\begin{array}{l}\text { Trên thực tế, chả có bà vợ nào thấy } \\
\text { chồng ngủ hết người này tới người } \\
\text { khác mà ngồi yên phân tích rồi khóc } \\
\text { với chả lóc } \\
\end{array}$ \\
\hline 81 & https://www.youtube.com/watch?v=zT7mqK4S8SA & La với chả hét \\
\hline 82 & https://www.facebook.com/watch/?v=709457359634824 & $\begin{array}{l}\text { Ăn học không lo suốt ngày lên với } \\
\text { chả xuống }\end{array}$ \\
\hline 83 & http://f319.com/threads/len-voi-cha-xuong-nhuc-ca-oc.284655/ & Lên với chả xuống, nhức cả óc \\
\hline 84 & 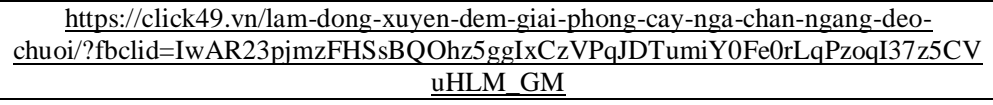 & Mưa với chả gió, nguy hiểm quá \\
\hline 85 & http://m.baokontum.com.vn/toa-soan-ban-doc/mua-mua-ha-15393.html & mưa với chả gió, cứ thích là mưa \\
\hline 86 & 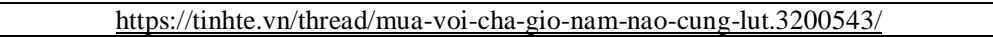 & Mưa với chả gió. Năm nào cũng lụt \\
\hline 87 & agram.com@hoang.tranvietbao & $\begin{array}{l}\text { "Mưa với chả gió, chỉ muốn ở nhà } \\
\text { Netflix and chill, hoặc thức dậy ăn ... }\end{array}$ \\
\hline 88 & https://www.cuoida.com/2020/12/noi-voi-cha-nangtodanpho69-dieucay.html & Nói với chả năng \\
\hline 89 & https://www.facebook.com/todanpho69/posts/5041500442534434/ & Nói với chả năng \\
\hline 90 & https://truyenwiki1.com/chuong-truyen/239902-562609458/ & Ôm với chả ấp \\
\hline 91 & $\begin{array}{l}\text { https://afamily.vn/hang-tui-bau-sap-de-ma-chong-van-nghien-me-met-dinh-vao-om- } \\
\text { mot-cai-nhung-thay-canh-ngang-trai-danh-ten-to-di-ra-20201008235349517.chn }\end{array}$ & $\begin{array}{l}\text { Mà cũng chả còn chỗ nào nằm mà } \\
\text { ôm với chả âp }\end{array}$ \\
\hline 92 & https://www.youtube.com/watch?v=qPVL7eZIVZ8 & Ở trường mà còn ôm với chả ấp \\
\hline 93 & $\begin{array}{c}\text { https://kenh14.vn/mua-dong-khong-nhan-thinh-he-lo-phien-ban-loi-cua-trao-luu-vong- } \\
\text { tay-om-gay-sot-mang-xa-hoi-20171213173017461.chn }\end{array}$ & Này thì ôm với chả ấp \\
\hline 94 & https://zingtruyen.net/chapter/hankisa-sweetheart/282052135/bi-mat/1118643873.html & $\begin{array}{l}\text { Hai thằng con trai mà suốt ngày ôm } \\
\text { với chả ấp }\end{array}$ \\
\hline
\end{tabular}




\begin{tabular}{|c|c|c|}
\hline 95 & https://gettruyen.com/thanh-dia-vui-thay.40613/chuong-66.7609128 & $\begin{array}{l}\text { Ôm với chả ấp, còn không mau đỡ } \\
\text { anh mày ngồi dậy, tôi lầm bầm lầu } \\
\text { bầu liếc qua vai thằng Nam xem } \\
\text { những người còn lại trong đội. }\end{array}$ \\
\hline 96 & http://truyen99.com/doc-chuong/alljoon-doan-sugamon/562879902.html & $\begin{array}{l}\text { Con lạy mấy bố! Đám cưới đã bắt } \\
\text { đầu rồi mà con ôm với chả ấp cái gì? }\end{array}$ \\
\hline 97 & https://cungcongcong.com/sh-1/ & $\begin{array}{c}\text { Mới gặp mà ôm với chả ấp thế rồi } \\
\text { đấy }\end{array}$ \\
\hline 98 & $\frac{\text { https://123docz.net/document/4378415-tieu-pham-du-thi-phong-chong-bao-luc-gia- }}{\underline{\text { dinh.htm }}}$ & $\begin{array}{l}\text { Tôi không biết cô đi mà tìm Ong với } \\
\text { chả Bướm....Hừm (với thái độ bực } \\
\text { tức, hành động mạnh). }\end{array}$ \\
\hline 99 & https://www.facebook.com/1027174914090090/posts/1876369089170664/ & $\begin{array}{l}\text { Ong với chả bướm } \\
\text { Từ nay Dỗi thật }\end{array}$ \\
\hline 100 & $\frac{\text { https://www.facebook.com/buquadi/posts/254200125941591?comment_id=255237349 }}{\underline{171202}}$ & Quần với chả áo \\
\hline 101 & https://www.facebook.com/SGUni.CFS/posts/609543079575155/ & Sách với chả vở \\
\hline 102 & https://m.facebook.com/Badaotv.vn/posts/269242091080864 & Sách với chả vở \\
\hline 103 & $\begin{array}{c}\text { https://m.facebook.com/thanvoichathoai/photos/a.2790561594303691/31093872924211 } \\
\text { 18/?type=3\&eid=ARAlqK_49soJBJp05al3d4ptD- } \\
\text { oAQqv0dE6xN8w8jbJevoRhjxYjmsOkiqC1v2LdjV-4MyIwyGfeYBNc }\end{array}$ & Thần với chả thoại \\
\hline 104 & https://trainghiemsong.vn/thay-boi-voi-cha-thay-bungbac-si-bao-cuoi-la-cuoi/ & $\begin{array}{l}\text { Thầy bói với chả thầy bủng... bác sĩ } \\
\text { bảo cưới là cưới! }\end{array}$ \\
\hline 105 & https://xabuon.com/content/314604-3--thi-voi-cha-cu--ngoi-ve-cho-choi---d.htm & Thi với chả cử, ngồi vẽ chơi chơi \\
\hline 106 & https://donghaeeunhyuk98.wordpress.com/2012/12/13/toc-voi-cha-tai/ & Tóc với chả tai \\
\hline 107 & $\begin{array}{c}\frac{\text { https://bestie.vn/2019/12/dua-doi-lam-toc-don-tet-chi-em-vo-mong-toc-voi-cha-tai-chi- }}{\text { phi-tien }} \\
\end{array}$ & $\begin{array}{l}\text { Đua đòi làm tóc đón tết, chị em vỡ } \\
\text { mộng "tóc với chả tai chỉ phí tiền" }\end{array}$ \\
\hline 108 & https://makeagif.com/gif/toc-voi-cha-tai-tea-theanh28video--Qwmey & Tóc với chả tai \\
\hline 109 & https://ikanruri.wordpress.com/2015/09/08/toc-voi-cha-tai/ & Tóc với chả tai \\
\hline 110 & $\begin{array}{c}\underline{\text { https://www.facebook.com/nem.thanh.huong.le/posts/2602547010024248?comment_id }} \\
\equiv 2625845024361113 \& \text { reply_comment_id=2625863051025977 }\end{array}$ & $\begin{array}{l}\text { Xe với chả cộ. Không đi thì thôi, hứa } \\
\text { với chả hèo làm nhân viên chờ } \\
\text { nguyên một ngày. }\end{array}$ \\
\hline 111 & https://www.youtube.com/watch?v=vSHk4eGyIxI & $\begin{array}{l}\text { Nhập được công hàng. xe với chả Cộ } \\
\text { chạy như thế này hỏng hết hàng rồi }\end{array}$ \\
\hline 112 & https://www.youtube.com/watch?v=p902tIXcxfs & $\begin{array}{l}\text { Ê Quá trời ơi xe với chả cộ cắt hết lỗ } \\
\text { cũng bán }\end{array}$ \\
\hline 113 & https://www.tiktok.com/@bp_thaonguyen1517/video/7014518863664565531 & $\begin{array}{l}\text { Đã nói hong có nhiều rồi mà cứ xin } \\
\text { với chả xỏ }\end{array}$ \\
\hline 114 & $\begin{array}{l}\text { https://voz.party/d/308578-ca-lang-viet-don-xin-tha-chet-cho-dua-con-9x-mang-an- } \\
\underline{\text { tu/32 }}\end{array}$ & $\begin{array}{l}\text { Giết con người ta rồi mà còn xin với } \\
\text { chả xỏ, nó còn muốn tự tử cơ mà, }\end{array}$ \\
\hline 115 & https://www.cuoida.com/2020/05/cm-yeu-voi-cha-uong-chia-tay.html & yêu với chả đương. Chia tay :) \\
\hline 116 & https://www.facebook.com/watch/?v=990653057945937 & Yêu với chả đương cái gì nữa \\
\hline 117 & $\begin{array}{c}\frac{\text { https://m.facebook.com/honghottv1/photos/a.112952750106841/197978388270943/?ty }}{\text { pe }=3 \& \_r d r} \\
\end{array}$ & Bị đặt yêu với chả đương cái gì! \\
\hline 118 & https://www.facebook.com/baithuoccotruyenhay/videos/2067515976858966/ & Ăn với chả uống nè, né nha \\
\hline 119 & https://baotreonline.com/giai-tri/biem-hoa/an-voi-cha-uong.baotre & $\begin{array}{c}\begin{array}{c}\text { Ăn với chả uống gì tầm này nữa, trễ } \\
\text { rồi }\end{array} \\
\end{array}$ \\
\hline 120 & https://www.dulichhoanmy.com/blog/chum-cuoi-qduq-voi-cha-qlichq & Du với chả lịch, hết thời gian \\
\hline 121 & https://twitter.com/hthh1004/status/1152935483489435649 & Hẹn với chả hò, còn đống việc đây. \\
\hline 122 & https://www.facebook.com/watch/?v=964009470764145 & Ôm với chả âp \\
\hline 123 & $\begin{aligned} & \text { https://doctruyenfull.net/doc-truyen/fanfic-than-tuong-thi-sao-dich-duong-thien-ti- } \\
& \underline{\text { tfboys/chap-4-om-om-om-568797488.html }}\end{aligned}$ & $\begin{array}{l}\text { Đã thế mây lần trước gặp thì không } \\
\text { ôm người ta đi, bày đặt chạy đi chỗ } \\
\text { khác cơ xong giờ lại nói muốn ôm } \\
\text { với chả ấp }\end{array}$ \\
\hline 124 & 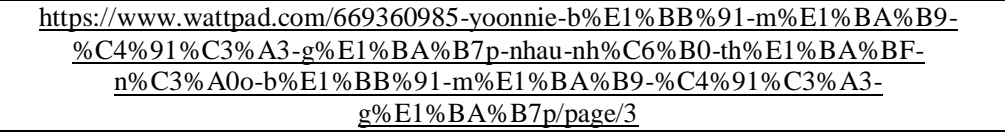 & $\begin{array}{l}\text { Chân thì như cái que mà bày đặt ôm } \\
\text { với chả âp! }\end{array}$ \\
\hline 125 & https://dbtgvn.net/tamly-giaoduc/detail/1922 & $\begin{array}{l}\text { Lớn rồi còn đòi ôm với chả ấp, em nó } \\
\text { cười cho. }\end{array}$ \\
\hline 126 & https://truyenhit.com/172162903-mau-vun/hai-muoi-sau-747852385/ & $\begin{array}{l}\text { Chinh cút ra, đã nóng thì chớ lại còn } \\
\text { ôm với chả âp, hôm nay tao cho mày } \\
\text { đi theo anh Huy anh Phượng đấy }\end{array}$ \\
\hline 127 & $\begin{array}{c}\text { https://xamvn.me/threads/theo-chung-mai-thay-thi-nen-di-htgd-massage-a-z-hay-la-di- } \\
\text { kiem-gai.21633/ }\end{array}$ & $\begin{array}{l}\text {....ôm thì dẹp đi ôm với chả ấp khó } \\
\text { chịu bỏ xừ }\end{array}$ \\
\hline 128 & https://truyenqt.com/tinh-yeu-lon-doi-toi/chuong-77 & $\begin{array}{l}\text { Thôi cút ra, nóng khiếp lên, ôm với } \\
\text { chả âp }\end{array}$ \\
\hline 129 & https://www.facebook.com/hhsb.vn/posts/5248709031810754 & $\begin{array}{l}\text { đừng rủ xem nữa nha, phim với chả } \\
\text { ảnh sợ lắm }\end{array}$ \\
\hline 130 & $\begin{array}{l}\frac{\text { https://kenh14.vn/quan-niem-song-ve-tien-bac-cua-keenu-reeves-toi-da-kiem-duoc-rat- }}{\text { nhieu-tien-toi-cho-di-rat-nhieu-va-song-don-gian-ta-deu-biet-rang-suc-khoe-tot-moi-la- }} \\
\text { dieu-quan-trong-hon-20200115122404863.chn }\end{array}$ & Tiền bạc chả có ý nghĩa gì với tôi cả. \\
\hline 131 & $\frac{\text { https://www.facebook.com/permalink.php?story_fbid=4411211095662844\&id=469869 }}{223130404}$ & $\begin{array}{c}\text { Trà với chả sữa đây này, đừng rủ nữa } \\
\text { nhé }\end{array}$ \\
\hline 132 & https://www.facebook.com/Tin-469869223130404 & Trà với chả sữa, xin bỏ từ nay \\
\hline
\end{tabular}




\begin{tabular}{|c|c|c|}
\hline 133 & $\frac{\text { https://nhandan.vn/tranghanoi-nho-nhe-nhac-nhau/\%c3\%90\%c3\%alng- }}{\text { bu\%e1\%bb\%93n-qu\%c3\%a1!-565570/ }}$ & $\begin{array}{l}\text { Xin với chả xỏ. Chỗ đông người,. đi } \\
\text { đứng phải cẩn thận chứ. }\end{array}$ \\
\hline 134 & https://www.facebook.com/anvoichauong/ & Ăn với chả uống \\
\hline 135 & https://www.facebook.com/watch/?v=995112104268067 & Anh với chả em \\
\hline 136 & https://www.facebook.com/watch/?v=693212451287428 & Cao với chả lùn. Thế có yêu không? \\
\hline 137 & https://www.youtube.com/watch?v=BW6pwdxFfHE & $\begin{array}{l}\text { chồng với chả con,cứ đẹp trai thế này } \\
\text { ai mà trịu được }\end{array}$ \\
\hline 138 & https://www.facebook.com/dongnhi/videos/769187583725495 & $\begin{array}{c}\text { Đáng với chả yêu thế này ai mà chịu } \\
\text { nổi chứ..... }\end{array}$ \\
\hline 139 & https://www.facebook.com/hhsb.vn/posts/5249239405091050 & $\begin{array}{l}\text { sang chảnh chưa, hình với chả bóng } \\
\text { phải chụp zi mới đẹp nè hehehehee }\end{array}$ \\
\hline 140 & https://www.facebook.com/watch/?extid=SEO----\&v=447349726375343 & $\begin{array}{l}\text { Lên với chả xuống, quất luôn cho } \\
\text { anh đi }\end{array}$ \\
\hline 141 & https://www.instagram.com.tradaodenda & Ai rảnh mà ôm với chả ấp :)) \\
\hline 142 & https://www.facebook.com/thayhintavungocanh/videos/190985783150067 & $\begin{array}{l}\text { Động lực là đây chứ đâu, tiền với chả } \\
\text { bạc thế này ai cũng mê và cố gắng } \\
\text { heheehehehe }\end{array}$ \\
\hline 143 & $\begin{array}{l}\frac{\text { https://www.facebook.com/whozthatgirlEXID/photos/t\%C3\%B3c-v\%E1\%BB\%9Bi- }}{\text { ch\%E1\%BA\%A3-tai-/1093699450735917/-v\%E1\%BB\%9Bi-ch\%E1\%BA\%A3-tai- }} \\
/ 1093699450735917 /\end{array}$ & Tóc với chả tai! \\
\hline 144 & https://www.facebook.com/watch/?v=610664353141188 & ai \\
\hline 145 & $\begin{array}{c}\text { https://www.facebook.com/tuyetdinhpowerpoint/photos/a.115217620147889/39142949 } \\
\text { 5860032/ }\end{array}$ & $\begin{array}{l}\text { Đúng là tuyệt với chả vời là ở đây hết } \\
\text { này... cảm ơn add nhe, rất hữu ích }\end{array}$ \\
\hline 146 & https://www.facebook.com/photo?fbid=438130384340193\&set=pcb. 438132164340015 & $\begin{array}{l}\text { Xinh với chả đẹp như gia đình chị thì } \\
\text { ai chẳng thích chị ơi,,, chúc chị hạnh } \\
\text { phúc nhe }\end{array}$ \\
\hline 147 & $\begin{array}{l}\text { https://m.facebook.com/honghottv1/photos/a.112952750106841/197978388270943/?ty } \\
\text { pe=3\& rdr }\end{array}$ & Bị đặt yêu với chả đương cái gì! \\
\hline 148 & https://www.facebook.com/watch/?v=990653057945937 & Yêu với chả đương cái gì nữa \\
\hline 149 & https://www.facebook.com/chipboygametv/posts/3200133356672634 & $\begin{array}{l}\text { Khóc với lóc cái gì em ơi, chiều nay } \\
\text { anh đưa em đi chơi :))) }\end{array}$ \\
\hline 150 & https://www.youtube.com/watch?v=fSxMmK3YxJ4 & $\begin{array}{l}\text { Yêu với đương cái gì hả yêu với } \\
\text { đương cái gì! }\end{array}$ \\
\hline 151 & https://www.youtu & cái gì \\
\hline 152 & https://www.goodies.vn/ & gì Tshirt \\
\hline 153 & https://www.fa & Cà với phê cái gì giờ này nữa. \\
\hline 154 & https://www.facebook.com/groups/523456052157384 & $\begin{array}{c}\text { Khóc với lóc cái gì, chia tay rồi thì } \\
\text { thôi }\end{array}$ \\
\hline 155 & https://www.facebook.com/TramCamXucSo1/videos/314262827179753 & Đòi với hỏi cái gì, vậy là được rồi \\
\hline 156 & os://www.facebook.com/EmKhongLaNangTh & i gì khi đã \\
\hline 157 & https://www.facebook.com/mautim.tinhyeu2014/videos/1424677127659862 & Nhớ với nhung cái gì nữa, hết rồi \\
\hline 158 & https://m.facebook.com/photo.php/?fbid=189497985762844 & $\begin{array}{l}21 \text { tuối độ tuối ăn chưa no lo chưa tới } \\
\text { thì chồng với con cái gì }\end{array}$ \\
\hline 159 & $\frac{\text { http://thuviendongthap.com/ebook/TO_QUOC_GOI/t\%201\%20p\%202/files/basic- }}{\text { html/page62.html }}$ & Học với hành cái gì ở đây \\
\hline 160 & $\begin{array}{l}\text { https://dtruyen.com/em-dinh-tron-tranh-den-bao-gio/xin-chao-anh-la-chu-khanh-phong- } \\
\text { 815086.html }\end{array}$ & chớ đâu phải để học với hành cái gì \\
\hline 161 & https://bau.vn/chong-kieu-nay-thi/ & $\begin{array}{l}\text { Không dỗ dành gì hết, đi làm cả ngày } \\
\text { mệt đứt hơi còn con với cái cái gi” }\end{array}$ \\
\hline 162 & https://www.facebook.com/cogaia.ngungthanvan & $\begin{array}{c}\text { Than với vãn làm chi, mất cũng mất } \\
\text { rồi }\end{array}$ \\
\hline 163 & https://www.facebook.com/pcstcvndx/photos/a.115503356973312/119955 & bớt than với vãn lại nha \\
\hline 164 & " & lừa với dối đầy ra, chả muốn quen ai \\
\hline 165 & $\frac{\text { https://www.facebook.com/pageyeu.office/photos/a.1851882951713123/323019456721 }}{5281 /}$ & $\begin{array}{l}\text { hứa với hẹn cho lắm vào cũng chia } \\
\text { tay }\end{array}$ \\
\hline
\end{tabular}

\section{REFERENCES}

[1] Beljan, M. (2015). Infixation in English varieties over the world. Osijek: Josip Juraj Strossmayer University of Osijek.

[2] Crowley, T. M. (1983). Uradhi. In R. Dixon, \& B. J. Blake, Handbook of Australian Languages (Vol. 3, pp. 306-428). Canberra: The Australian National University Press.

[3] Elfner, E., \& Kimper, W. (2008). Reduplication without RED: Evidence from Diddly-infixation. Proceedings of the 27th West Coast Conference on Formal Linguistics (pp. 150-158). MA: Cascadilla Proceedings Project,.

[4] Lindsay, M. (2010). American English iz-infixation: Interaction of phonology, metrics and rhyme. In H. Bliss, M. Louie, \& M. Schellenberg (Ed.), Northwest Linguistics Conference. 25, pp. 159-172. Vancouver: The University of British Columbia Working Papers in Linguistics.

[5] Mattiello, E. (2013). Extra-grammatical Morphology in English: Abbreviations, Blends, Reduplicatives, and Related Phenomena. Berlin/Boston: De Gruyter Mouton.

[6] McCarthy, J. J. (1982). Prosodic structure and expletive infixation. Language, 58(3), 574-590.

[7] Nguyen, P. P. (1976). Le syntagme verbal en vietnamien. La Haye, Paris: Mouton. 
[8] Noyer, R. (1998). Vietnamese 'Morphology' and the Definition of Word. University of Pennsylvania Working Papers in Linguistics, 5(2), 65-89.

[9] Rischel, J. (1995). Minor Mlabri: A Hunter-Gatherer Language of Northern Indochina. Copenhagen: Museum Tusculanum Press.

[10] Thompson, L. C. (1963). The Problem of the Word in Vietnamese. Word, 19(1), $39-52$. doi:https://doi.org/10.1080/00437956.1963.11659787

[11] Ultan, R. (1975). Infixes and their origins. In H. Seiler, Linguistic workshop III: Arbeiten des Kölner Universalienprojekts 1974 (pp. 157-205). Munich: Wilhelm Fink Verlag.

[12] Yu, A. (2003). The Morphology and Phonology of Infixation. Berkeley: University of California, Berkeley.

[13] Zwicky, A. M., \& Pullum, G. K. (1987). Plain Morphology and Expressive Morphology. Proceedings of the Thirteenth Annual Meeting of the Berkeley Linguistics (pp. 330-340). Berkeley: Berkeley Linguistics Society. doi:https://doi.org/10.3765/bls.v13i0.1817
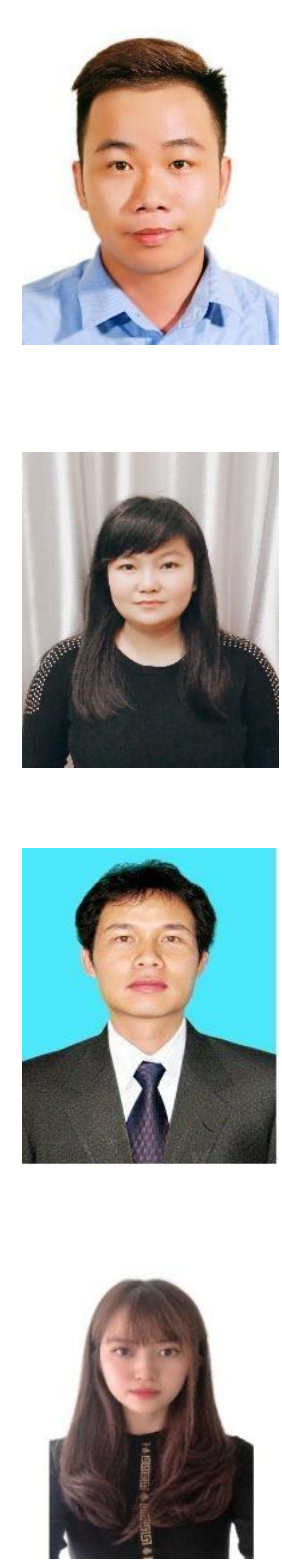

Nguyen Vi Thong is currently a lecturer of English at the Faculty of Foreign Languages, Dalat University, Vietnam. He received his Ph.D. in linguistics from National Chung Cheng University in Taiwan in 2020. His research interests include sociolinguistics, pragmatics, discourse analysis, cognitive studies, and translation.

Email: thongnv@dlu.edu.vn

Google Scholar: https://scholar.google.com.tw/citations?user=d27ot30AAAAJ\&hl=en

ORCID ID: https://orcid.org/0000-0002-9163-5110

Nguyen Hoang Nhat Khanh is a lecturer of English at Dalat University, Vietnam. She finished her master's program of English studies in 2019. Her research interests include applied linguistics and TESOL.

Email:khanhnhn@dlu.edu.vn

Scopus Author ID: https://www.scopus.com/authid/detail.uri?authorId=57224767821

ORCID ID: https://orcid.org/0000-0001-6074-9935

Nguyen Tat Thang is a lecturer of English at Dalat University, Vietnam. He received the title of Associate Professor in linguistics in 2017. His interests are semantics, SLA, and socio-linguistics.

Email: thangnt@dlu.edu.vn

Scopus Author ID: https://www.scopus.com/authid/detail.uri?authorId=57212462062

ORCID ID: https://orcid.org/0000-0001-8486-2385

Nguyen Hoang Nhat Quyen is a lecturer of English at Dalat University, Vietnam. She finished her master's program of English studies in 2019. Her research interests include applied linguistics and TESOL.

Email: quyennhn@dlu.edu.vn

Scopus Author ID: https://www.scopus.com/authid/detail.uri?authorId=57224785029

ORCID ID: https://orcid.org/0000-0001-6038-557X 


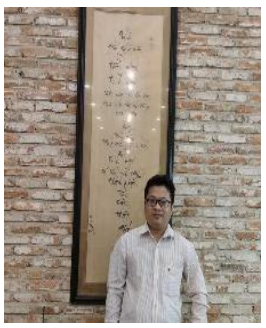

Tran Tin Nghi is a lecturer in the Foreign Languages Faculty, Ho Chi Minh City University of Food Industry. $\mathrm{He}$ is also a member of STESOL, a part of the Association of Vietnam Universities and Colleges. His research interests are Teaching English as a Foreign Language, CALL, corpus linguistics, and cognitive linguistics.

Email: nghitt@hufi.edu.vn

Scopus Author ID: https://www.scopus.com/authid/detail.uri?authorId=57212464873

ORCID ID: https://orcid.org/0000-0001-6549-3895 